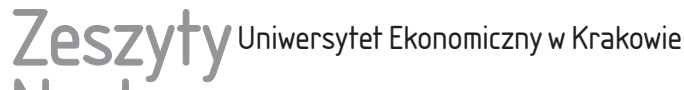 Naukowe
}

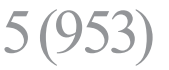

ISSN 1898-6447

Zesz. Nauk. UEK, 2016; 5 (953): 21-32 DOI: 10.15678/ZNUEK.2016.0953.0502

Tomasz Tylec

\section{Koncepcja uwarunkowań instytucjonalnych w nowej ekonomii instytucjonalnej*}

\section{Streszczenie}

Rola instytucji w rozwoju i funkcjonowaniu całej gospodarki jest jednym z najciekawszych obszarów badawczych nowej ekonomii instytucjonalnej. W nurcie tym kryterium minimalizacji kosztów transakcyjnych zostało wykorzystane zarówno do analizy życia gospodarczego, jak i wszelkich innych instytucji społecznych. Celem artykułu jest przedstawienie problematyki występowania kosztów transakcyjnych oraz znaczenia uwarunkowań instytucjonalnych rynków i działalności gospodarczej. W tym kontekście zarysowano problem powstawania i zmiany ram instytucjonalnych oraz wskazano na złożoność i specyfikę tego procesu.

Słowa kluczowe: koszty transakcyjne, instytucje, nowa ekonomia instytucjonalna, path dependence.

Klasyfikacja JEL: B25, D02.

\section{Wprowadzenie}

W ramach nowej ekonomii instytucjonalnej poddaje się analizie instytucje jako czynnik decydujący o wysokości kosztów transakcyjnych w procesie koor-

Tomasz Tylec, Uniwersytet Ekonomiczny w Krakowie, Katedra Mikroekonomii, 31-510 Kraków, ul. Rakowicka 27, e-mail: tylect@uek.krakow.pl

* Artykuł powstał w ramach tematu badawczego sfinansowanego ze środków przyznanych Wydziałowi Ekonomii i Stosunków Międzynarodowych Uniwersytetu Ekonomicznego w Krakowie w ramach dotacji na utrzymanie potencjału badawczego. 
dynacji wykorzystania rzadkich zasobów. W takim ujęciu instytucje mają duże znaczenie dla funkcjonowania całej gospodarki i powinny być przedmiotem analizy ekonomicznej.

Celem artykułu jest próba odniesienia się do koncepcji kosztów transakcyjnych i instytucji tkwiących u podstaw nowej ekonomii instytucjonalnej oraz znaczenia uwarunkowań instytucjonalnych w postaci kompletnego i efektywnego systemu instytucjonalnego. W opracowaniu starano się udowodnić tezę, że uwarunkowania instytucjonalne w postaci kompletnego i sprawnego systemu instytucjonalnego umożliwiają właściwą alokację zasobów w gospodarce. W tym kontekście zwrócono również uwagę na tworzenie ram instytucjonalnych oraz złożoność tego procesu.

W artykule zarysowano koncepcję kosztów transakcyjnych w ujęciu głównych przedstawicieli tego nurtu, następnie zwrócono uwagę na instytucje i uwarunkowania instytucjonalne działalności gospodarczej oraz na złożony proces ich powstawania.

\section{Rynki i hierarchie jako różne rodzaje struktur współrządzenia}

Według R. Coase'a przedsiębiorstwo w ujęciu teorii neoklasycznej określone jest przez krzywą kosztów i krzywą popytu, a jego teoria jest optymalizacją w zakresie wyceny nakładów i ich łączenia, konsument zaś jest określony tylko przez układ preferencji. Wymiany rynkowe z kolei dokonuje się bez określenia uwarunkowań instytucjonalnych. Wszystko to oznacza „konsumentów bez cech ludzkich, przedsiębiorstwa bez struktur organizacyjnych, a nawet wymianę bez rynków" [Coase 1990, s. 3] oraz przekłada się na dość słaby związek tych teorii z rzeczywistością gospodarczą. Efektem tego typu rozważań jest oderwana od rzeczywistości „ekonomia na tablicy” (blackboard economics) [Coase 1992, s. 714].

Biorąc pod uwagę te ograniczenia, R. Coase starał się odpowiedzieć na pytanie, dlaczego istnieją przedsiębiorstwa, skoro system cenowy stanowi wystarczający mechanizm koordynacji. Wyjaśnienie oparte zostało na założeniu, że aktywność na rynku związana jest z powstaniem kosztów transakcyjnych [Coase 1937]. Oznacza to, że przedsiębiorstwo jest instytucją zastępującą rynek i zapewniającą korzyści dzięki ograniczeniu kosztów transakcyjnych ${ }^{1}$.

\footnotetext{
${ }^{1}$ Koszty transakcyjne są definiowane jako koszty konieczne do ustanowienia i utrzymania sytemu reguł i praw. Jeżeli instytucje są wiązkami reguł, wówczas koszty transakcyjne są związanymi z nimi kosztami ustanowienia i utrzymania tych instytucji. Są kosztami unikania niepożądanych zachowań [Allen 2011, s. 895]. Koszty transakcyjne jako kryterium formuły współpracy stanowią podstawowy problem badawczy nowej ekonomii instytucjonalnej. Mimo ogólnej akceptacji
} 
Tym samym istnienie kosztów transakcyjnych stanowi uzasadnienie alternatywnej wobec rynku metody koordynacji, tj. koordynacji w ramach przedsębiorstwa przez hierarchiczne zarządzanie [Coase 1937, s. 715].

Przedsiębiorstwo jako „małe planowane społeczeństwo” stanowi, zgodnie z teorią Coase'a, optymalny sposób koordynacji zasobów. Jej rozmiar jest efektem zastosowania analizy krańcowej, w ramach której przedsiębiorstwo internalizuje transakcje do momentu, gdy wewnętrzny koszt krańcowy zarządzania zrówna się z kosztami transakcji rynkowych. Oznacza to możliwość ustalenia optymalnego rozmiaru przedsiębiorstwa. Ponadto mimo sukcesu w procesie koordynacji zasobów, według kryterium minimalizacji kosztów transakcyjnych rosnące koszty zarządzania hierarchicznego umożliwiają odpowiedź na pytanie, dlaczego przedsiębiorstwo nie rozrasta się do monopolu pełnego, obejmującego całą gospodarkę. R. Coase uznał, że koszty transakcji składają się na ogólne koszty produkcji. Tym samym w procesie produkcji ma miejsce optymalizacja kosztów produkcji, jak i optymalizacja kosztów koordynacji zaangażowanych zasobów produkcyjnych [Coase 1990, s. 33-55]. Oznacza to, że wszystkie metody alokacji zasobów mają koszty i korzyści, a żaden mechanizm nie działa bez koszów i nie dominuje nad innym. Ostatecznie R. Coase dowiódł, że dodatnie koszty transakcji są zarówno konieczne, jak i wystarczające do wyjaśnienia istnienia przedsiębiorstwa [Allen 1999, s. 895].

O.E. Williamson [1975] wyróżnia rynki i hierarchie jako różne rodzaje struktur współrządzenia. Stwierdza ponadto, że wraz z pojawieniem się zachowań oportunistycznych (kłamstw i oszustw) u poszczególnych jednostek biorących udział w wymianie rynkowej, organizowanie produkcji oraz zawieranie transakcji w organizacji hierarchicznej (np. przedsiębiorstwie) może być bardziej pożądane niż rynek, czyli może zapewniać niższe koszty produkcji [Williamson 1998a]. Według O.E. Williamsona wzrost kosztów transakcyjnych jest z jednej strony skutkiem ograniczonych zdolności poznawczych jednostki, a z drugiej rosnącej złożoności i niepewności wynikającej ze skłonności do zachowań oportunistycznych połączonej z niewielką liczbą potencjalnych partnerów wymiany.

Zdaniem O.E. Williamsona [1998a, s. 65 i nast.] na ryzyko transakcji wpływa rodzaj stosowanej technologii. Wykorzystanie rynku (jako struktury współrządzenia) staje się bardziej kosztowne, gdy dotyczy specyfiki zaangażowanego w transakcję kapitału (asset specifity) lub inwestycji specyficznych dla danej transakcji (transaction-specific investments), np. z równocześnie przekazywaną technologią [Williamson 1998b, s. 38]. Do niektórych form specyfiki zaanga-

zjawiska występowania tych kosztów w gospodarce, w literaturze przedmiotu nie wypracowano jednej definicji tego pojęcia. Ich cechą jest zewnętrzne względem kosztów produkcji pochodzenie oraz trudność ich pomiaru i wyrażenia w jednostkach pieniężnych. Ich istotę oddaje zjawisko tarcia w fizyce [Furubotn i Richter 2000, s. 40]. 
żowanego kapitału należą aktywa fizyczne, kapitał społeczny, lokalizacja czy nazwa marki [Williamson 1998b, s. 37]. Dzieje się tak z powodu pogłębiającej się wzajemnej zależności stron zaangażowanych w transakcję i rosnącego w związku z tym zagrożenia wystąpienia zachowań oportunistycznych. Oznacza to, że w sytuacji przedsiębiorstwa uzależnionego od jednego dostawcy pojawia się ryzyko zmiany warunków umowy już po jej zawarciu. Jeżeli koszty dodatkowych zabezpieczeń stają się zbyt wysokie, konieczne jest przesunięcie produkcji do przedsiębiorstwa (w celu ograniczenia kosztów transakcyjnych). Gdy w przedsiębiorstwie nie występuje specyficzny zaangażowany w transakcję kapitał, rynek może stanowić bardziej efektywną formę instytucjonalną organizacji zasobów.

Zjawisko to O.E. Williamson [1998a, s. 65 i nast.] wyjaśnia poprzez wypieranie przedsiębiorstw typu $\mathrm{U}$ (unilateral) przez przedsiębiorstwa $\mathrm{w}$ formie $\mathrm{M}$ (multi-divisioned). Przyjmuje, że stanem pierwotnym jest przedsiębiorstwo typu U oraz niedoskonałe rynki pracy i kapitału. Tworząc przedsiębiorstwo typu M, istnieje możliwość zwiększenia efektywności alokacji zasobów przedsiębiorstwa poprzez stworzenie wewnętrznego rynku pracy i kapitału. Swoista „internalizacja” rynku pracy i kapitału zapewnia lepszy dostęp do informacji oraz zwiększa możliwości przeciwdziałania oportunizmowi wewnętrznemu.

Można w związku z tym przyjąć, że przed powstaniem instytucji koordynującej, jaką jest przedsiębiorstwo, istniała instytucja w postaci niedoskonałego rynku. W związku z tym przedsiębiorstwo często traktuje się jako innowację instytucjonalną zastępującą instytucję rynku w zakresie, w jakim możliwe jest osiągnięcie korzyści w postaci niższych kosztów transakcyjnych wynikających z koordynacji zasobów wewnątrz przedsiębiorstwa (w tym przypadku, unikając kosztów transakcyjnych na rynku, ponoszone są koszty koordynacji wewnętrznej). O.E. Williamson [1998b, s. 37] zauważa, że bodźce występujące na rynkach oparte są na konkurencji, natomiast bodźce w przedsiębiorstwach opierają się na procedurach administracyjnych oraz współpracy, w ramach której niezwykle istotne jest zaufanie.

Przedstawiony opis różnych struktur współrządzenia (rynek v. hierarchie) można zatem wyjaśnić przez swoistego rodzaju continuum, w ramach którego analizę można prowadzić od całkowitego braku powiązań między poszczególnymi graczami rynkowymi (przedsiębiorstwami) aż po istnienie przedsiębiorstwa zorganizowanego hierarchicznie (rys. 1). Między tymi skrajnościami występują pośrednie formy struktur współrządzenia (luźne sieci współpracy, umowy o współpracy, joint-ventures itp.), tzw. hybrydy organizacyjne.

O wyborze danej struktury zarządzania ma decydować technologia. Jeżeli $k$ oznacza specyficzne aktywa zaangażowane w transakcję, to $k$ będzie równe 0 w transakcjach, w których wykorzystano powszechną technologię. W przypadku specyficznej technologii, $k>0$, czyli sytuacji silnego uzależniania stron 
kontraktu, konieczne staje się wprowadzenie odpowiednich zabezpieczeń $s$, $s>0$ (gdy nie stosuje się żadnych zabezpieczeń wówczas $s=0$ ). Zabezpieczenia mogą pojawić się dwóch postaciach: 1) jako wprowadzenie do umowy odpowiednich zapisów i klauzul określających sankcje za naruszenie przyjętych ustaleń; 2) zastąpienie rynkowego mechanizmu koordynacji hierarchią (struktury zarządzania transakcjami) przez przedsiębiorstwo, tj. internalizacja kontraktów rynkowych w ramach przedsiębiorstwa. W przypadku A nie występuje zależność związana ze specyfiką wykorzystanej w transakcji technologii $(k=0)$, a zabezpieczaniem transakcji jest rynkowy mechanizm konkurencji $(s=0)$. W przypadku B występuje ryzyko związane z zawartym kontraktem $\mathrm{w}$ związku z inwestycją w specyficzne aktywa $(k>0)$, jednak nie ma zabezpieczeń kontraktu $(s=0)$. $\mathrm{W}$ cenie kontraktu uwzględnione zostaje ryzyko jego zerwania. W przypadku $\mathrm{C}$ w związku $\mathrm{z} k>0$ zastosowano dodatkowe zabezpieczenia w postaci szczegółowych postanowień kontraktu $(s>0)$. Przypadek D to sytuacja z $k>0$ i zabezpieczeniem w postaci integracji w ramach jednej struktury własności (integracja pionowa).

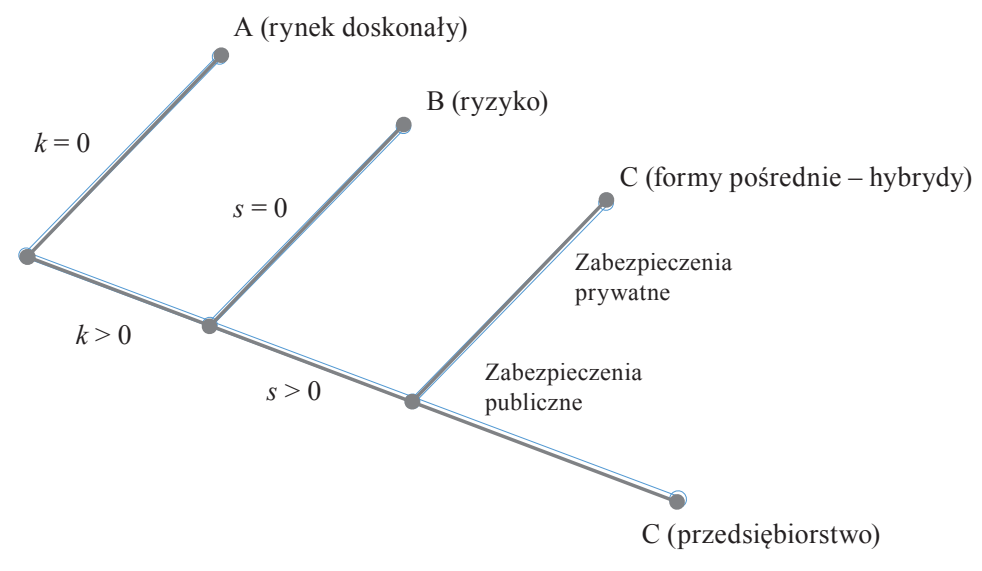

Rys. 1. Struktury zarządzania transakcjami (rynek, struktury pośrednie, hybrydy, przedsiębiorstwo)

Źródło: [Williamson 2000].

O.E. Williamson [1998a, s. 33] podzielił koszty transakcyjne odpowiednio do fazy kontraktowania na koszty ex ante, na które składają się nakłady ponoszone w trakcie przygotowywania i negocjowania umów, związane z pozyskaniem odpowiednich informacji, i ex post ponoszone i związane z tworzeniem struktury zarządzania transakcją i jej wykorzystaniem do monitorowania przebiegu 
umowy, ubezpieczeniem umowy czy kosztami ewentualnego postępowania sądowego. Koszty transakcyjne powstają niezależnie od poziomu współpracy nie tylko na tradycyjnym rynku, na którym działają niezależne podmioty oraz w przedsiębiorstwach lub innych organizacjach, ale także na rynku politycznym, gdzie pojawiają się specyficzne koszty transakcyjne związane z kontraktami publicznymi [Buchanan i Tullock 1997, s. 304]².

\section{Uwarunkowania instytucjonalne funkcjonowania rynków}

Istnienie kosztów transakcyjnych spowodowało, że ekonomiści zwrócili uwagę na uwarunkowania instytucjonalne działania rynków3 ${ }^{3}$ Stało się bowiem oczywiste, że sprawne funkcjonowanie rynków zależy od instytucji (w tym jakości otoczenia prawnego, zasad moralnych i mentalności graczy) oraz sprawności systemu przestrzegania przyjętych reguł prawnych, które przekładają się na poziom zaufania społecznego i transparentność warunków, w jakich przebiega „gra" rynkowa. Zainteresowanie instytucjami wynika z przekonania, że decydują one o znacznej części kosztów produkcji - kosztów, których udział w ogólnych kosztach produkcji rośnie wraz z rozwojem podziału pracy, a których tradycyjna ekonomia nie uwzględnia [Godłów-Legiędź 2005, s. 29].

Instytucje definiuje się jako zbiór ograniczeń nakładanych na zachowania jednostek w formie reguł i regulacji, zbiór procedur służących do wykrywania odchyleń od reguł i regulacji, zbiór norm moralnych, etycznych i behawioralnych,

2 Za J. Małyszem [2003, s. 315-340] można wyróżnić trzy rodzaje kosztów transakcyjnych: 1) rynkowe koszty transakcyjne, na które składają się koszty poszukiwania i gromadzenia informacji, zawarcia umowy oraz nadzorowania jej wykonania; 2) wewnątrzfirmowe koszty transakcyjne, do których zalicza się koszty funkcjonowania przedsiębiorstwa związane z utrzymaniem i modernizacją struktury organizacyjnej przedsiębiorstwa niezależne od wielkości obrotów (traktowane jako koszty stałe) oraz koszty podejmowania decyzji, nadzoru, pomiaru, przetwarzania informacji, prowadzenia działalności czy też koszty związane z logistyką wewnątrz przedsiębiorstwa, koszty zmienne oraz 3) publiczne koszty transakcyjne, w których skład wchodzą koszty organizacji, utrzymania i modernizacji formalnego i nieformalnego porządku publicznego „danego systemu politycznego, społecznego i ekonomicznego (stworzenia porządku prawnego, publicznego zarządzania, obronności, systemu wychowania i kształcenia, sądownictwa) oraz koszty funkcjonowania społeczeństwa (bieżące wydatki na ustawodawstwo, obronę kraju, komunikację, kształcenie, podejmowanie decyzji publicznych oraz ich egzekwowanie).

3 System uwarunkowań instytucjonalnych jest istotny, gdyż mechanizm rynkowy ze swej natury nie zapewnia zrównoważonej struktury instytucjonalnej i trwałości rozwoju, nie zapewnia odpowiedniej koordynacji w zakresie celów środowiskowych, ekonomicznych i społecznych i nie jest ukierunkowany na cele długookresowe. W ramach mechanizmu rynkowego artykułowane są interesy wąskiej grupy właścicieli kapitału rzeczowego i finansowego, oparte na wąskiej i niespójnej strukturze instytucjonalnej, zdominowanej przez ekonomiczne i polityczne interesy wybranych grup [Polanyi 1944, s. 68]. 
które określają zakres sposobu tworzenia i umocowania reguł i regulacji [North 1984, s. 204]. Te wymyślone przez ludzi ograniczenia w postaci reguł postępowania, które kształtują i porządkują ich wzajemne relacje, strukturyzują bodźce postępowania w sferze ekonomicznej, politycznej i społecznej. D.C. North [1997, s. 2-4; 1990, s. 36] dzieli je na instytucje (ograniczenia) formalne i nieformalne.

Instytucje formalne to normy prawne regulujące stosunki polityczne, w tym sądownicze (rozwiązania ustrojowe w zakresie systemu politycznego) i ekonomiczne (prawo własności) oraz prawo kontraktowe. Instytucji nieformalnych nie można zdefiniować tak precyzyjnie, jak reguł formalnych. To normy pozwalające rozwiązać liczne problemy towarzyszące wymianie, nie w całości rozwiązywane przez normy prawne (instytucje formalne) oraz posiadające zdolność do trwałego utrzymywania się. Można do nich zaliczyć moralność, mentalność, rutynę, zwyczaj, tradycję oraz kulturę. Stanowią one pewną konwencję lub zwyczaj ewoluujący wraz z problemem koordynacji. Jednocześnie wszystkie strony transakcji są zainteresowane ich utrzymaniem (np. zasady zachowania się na drodze). Zalicza się do nich normy zachowania, które są uznawanym powszechnie standardem postępowania (np. w relacjach interpersonalnych w rodzinie, szkole, przedsiębiorstwie) czy samonarzucone reguły postępowania (rzetelność, uczciwość). Konwencje te jednostki narzucają sobie same. Normy zachowania są narzucane przez stronę transakcji (działanie odwetowe) lub stronę trzecią (sankcje społeczne lub przymus autorytetu), a ich skuteczność zależy od skuteczności instrumentów przymusu [North 1997, s. 4; North 1990, s. 36].

Ostatnim elementem systemu instytucjonalnego jest stopień i zdolność do przestrzegania ustalonych reguł. W przypadku reguł formalnych zależne jest to od bezwzględnego przestrzegania prawa (oraz sprawności wymiaru sprawiedliwości), a w przypadku norm zachowania - od skuteczności sankcji społecznych i wewnętrznej dyscypliny jednostek w zakresie rzetelności i uczciwości. Niemożność skutecznego przestrzegania postanowień kontraktów jest według D.C. Northa [1990, s. 54] najważniejszym czynnikiem stagnacji gospodarczej. Dlatego istnienie spójnego systemu norm formalnych oraz zgodnych z nimi norm nieformalnych, a także skutecznego systemu egzekucji prawa umożliwia stworzenie otoczenia instytucjonalnego zapewniającego efektywne działanie rynków. Funkcją tak określonego, stabilnego otoczenia instytucjonalnego jest zapewnienie przewidywalności zachowań partnerów transakcji, jak i całego otoczenia rynkowego. System instytucji oddziałuje również na decyzje technologiczne podmiotów dotyczące wielkości inwestycji, zakresu i okresu zaangażowania w wymianę, inwestycji w aktywa specyficzne itp. Nieefektywny system instytucji będący skutkiem gry sił politycznych i grup interesu może skutkować pogłębieniem nieefektywności rynków. 
Według O.E. Williamsona [1998a, s. 33] wśród ograniczeń instytucjonalnych można wyróżnić poziom uporządkowania jurydycznego (court orderin) oraz poziom porządku rynkowego w prywatnych transakcjach (private orderin). Poziom publiczny obejmuje instytucje złożone z zasad konstytucyjnych i innych źródeł prawa wraz z towarzyszącym im systemem zabezpieczeń i egzekucji. Poziom prywatny składa się z dostosowanych do różnych kontraktów konkretnych rozwiązań opierających się na moralnym zobowiązaniu do dotrzymania obietnicy, czyli na tzw. sankcjach pozaprawnych (utraty reputacji, wykluczenia $z$ innych transakcji, negatywnej wzajemności itp.). O.E. Williamson [2000] w sposób wyraźny podkreśla znaczenie podstaw moralnych i religijnych instytucji publicznych i prywatnych.

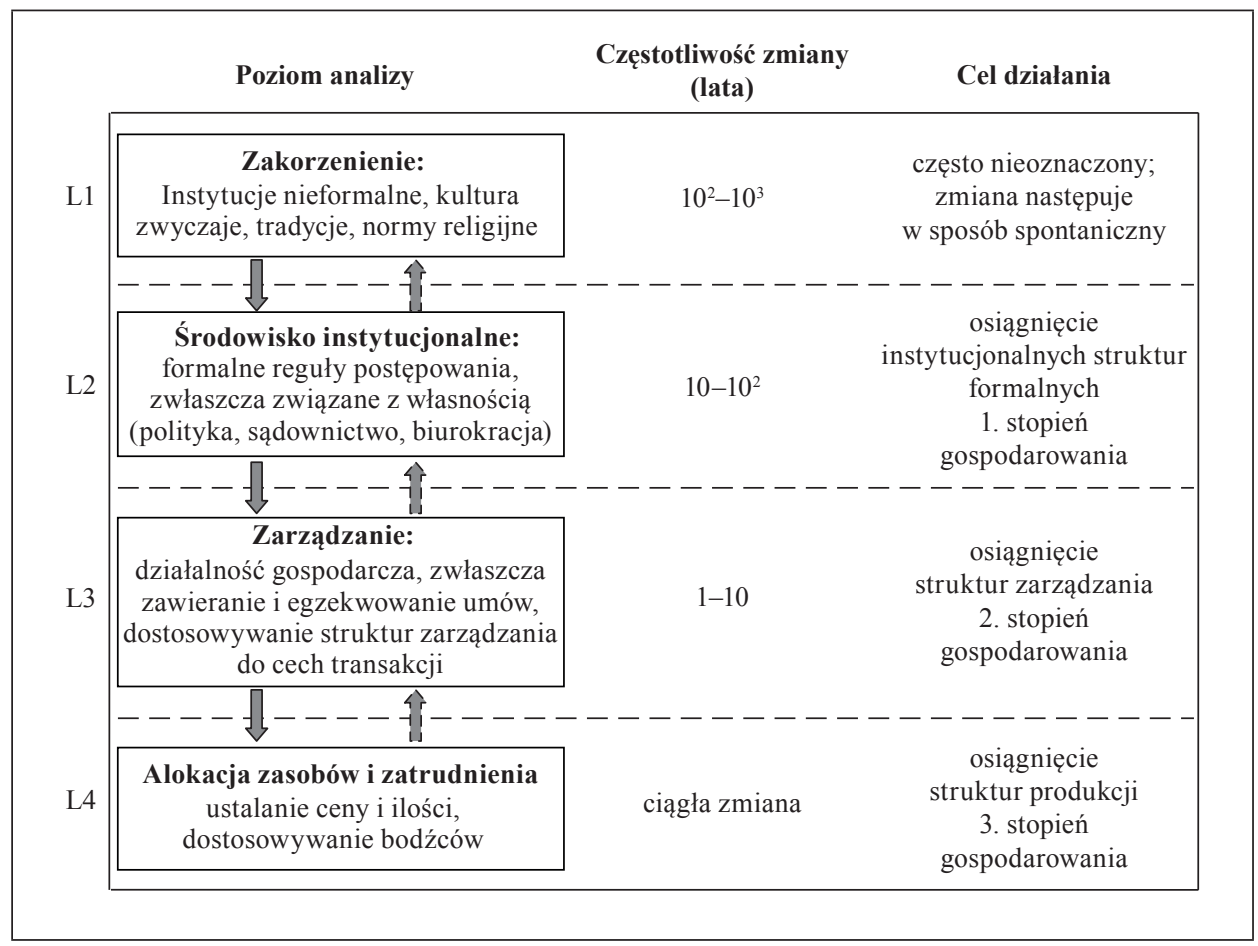

Rys. 2. Cztery poziomy analizy instytucji - schemat O.E. Williamsona Źródło: [Willamson 2000].

O.E. Williamson zwraca uwagę na fakt, że pierwotne reguły społeczne są potrzebne do ukształtowania instytucji. Wyodrębnia cztery poziomy społecznej analizy instytucji - sferę instytucji nieformalnych (L1), sferę instytucji formalnych (L2), sferę zarządzania (L3) oraz sferę alokacji zasobów (L4) [Williamson 
2000]. Poziom pierwszy obejmujący zwyczaje, tradycje, normy religijne i kulturę tworzy podstawę instytucji formalnych i publicznych w postaci zasad konstytucyjnych i prawa kontraktów (zob. rys. 2). Te z kolei składają się na otoczenie instytucjonalne, w którym ma miejsce proces „doprecyzowania reguł wymiany i konkurencji oraz alternatywnych sposobów koordynacji zasobów, a także proces tworzenia nowych rozwiązań instytucjonalnych" [Williamson 2000]. Z kolei otoczenie instytucjonalne tworzyć ma tzw. ścieżkę uzależnienia (path dependence), na podstawie której powstają instytucje nieformalne.

\section{Nowa ekonomia instytucjonalna wobec procesu kształtowania instytucji}

Podstawową tezą nowej ekonomii instytucjonalnej jest twierdzenie, że najlepszy nawet kształt norm formalnych nie wystarczy do uregulowania relacji między podmiotami. Za przyczynę tego stanu uznaje się występowanie kosztów transakcyjnych przy wymuszaniu respektowania norm formalnych oraz niekompletność umów dotyczących przyszłości [Lissowska 2008, s. 55]. Dlatego też głównym aspektem badań w ramach tej gałęzi ekonomii są instytucje trzeciego poziomu tworzone w celu regulowania współpracy pomiędzy podmiotami lub ich grupami. Powiązania ogólnych i ,prywatnych” reguł gry pomiędzy podmiotami gospodarującymi stanowią przedmiot badań wyodrębniony w zakresie analizy historyczno-porównawczej w nowej ekonomii instytucjonalnej [Lissowska 2008, s. 55]. W ramach tego kierunku instytucje określa się jako endogenicznie ukształtowane i samorealizujące się, nietechnologiczne ograniczenia interakcji społecznych. Wśród nich można wyróżnić reguły współdziałania nie tylko o charakterze ekonomicznym, ale i społecznym, obowiązujące na podstawie umowy lub przyjęte konwencje między poszczególnymi jednostkami oraz sformalizowane reguły ogólne. W ramach wymienionego kierunku analizie poddaje się dwa mechanizmy kształtowania instytucji.

Pierwszy mechanizm kształtuje i utrwala specyficzne cechy graczy przez internalizację warunków i uczenie się efektywnych zachowań, natomiast drugi eksponuje rolę nowych istotnych graczy i wpływ ich strategicznych zachowań na modyfikację reguł gry. W ramach kierunku analizy historyczno-porównawczej eksponuje się także aspekt dynamiki i charakteru ewolucji instytucji. Podstawą tego podejścia jest teza, że zmiany instytucjonalne, jako wynikające z działań podmiotów o ograniczonej wiedzy i racjonalności oraz będących pod wpływem poprzednio wprowadzonych instytucji, nie muszą oznaczać optymalnego dostosowania do środowiska. Widoczny jest tu element path dependence 
w przemianach instytucji. Ewolucja gry oraz rodzaj uzyskanej równowagi zależą od [Lissowska 2008, s. 55]:

- układu interesów uczestników,

- rodzaju stosowanych przez nich strategii,

- warunków strukturalnych (np. występowania monopolu lub rozdrobnienia, kosztów i ryzyka współpracy, asymetrii informacji).

Oznacza to, że zależnie od istniejących uwarunkowań rozwój gry może doprowadzić do różnych instytucji jako stanów stabilnych. Dlatego powiązania czynników warunkujących grę mogą doprowadzić do odmiennego ukształtowania się instytucji w krajach o podobnym systemie politycznym. Zgodnie z wynikami badań empirycznych dla gospodarki większe znaczenie ma komplementarność instytucji niż jednoznacznie określony ich typ, o czym świadczy istnienie w różnych krajach ukształtowanych historycznie systemów spójnych instytucji (np. system anglosaski, japoński, niemiecki). Jednak nie ma możliwości jednoznacznej oceny, który z tych systemów jest sprawniejszy. Na tej podstawie można wysnuć wniosek, że odwoływanie się do „uniwersalnych instytucji gospodarki rynkowej" nie znajduje uzasadnienia.

\section{Podsumowanie}

Większość podejmowanych przez ludzi działań uwarunkowanych jest instytucjami danego społeczeństwa, które z jednej strony tworzą zasady stanowiące oparcie dla ludzi starających się osiągać swoje cele, a z drugiej wyznaczają ramy działań poszczególnych jednostek. Niedojrzałość i niekompletność struktury instytucjonalnej może przekładać się na względnie niską efektywność systemu funkcjonowania gospodarki, w tym niższą produktywność czynników wytwórczych oraz gorszą pozycję konkurencyjną danej gospodarki. Spójna struktura instytucjonalna, u podstaw której powinny się znaleźć instytucje nieformalne w postaci kulturowego dziedzictwa norm i wartości (w tym norm moralnych) sprzyja akumulacji kapitału społecznego i współpracy, co przekłada się na osiąganie celów społecznych w zakresie powiększania dobrobytu i zamożności społeczeństwa. Jeżeli struktura instytucji nie jest spójna i w sposób kompleksowy uzupełniająca się, to z dużym prawdopodobieństwem nie będzie stwarzać możliwości osiągnięcia długookresowych celów społecznych, w tym ukierunkowanych na sukces gospodarczy. Istotny jest również fakt, że ukształtowany w danym społeczeństwie system instytucji nie jest łatwy do transferowania, dlatego też każde społeczeństwo zmuszone jest wypracować taki system samodzielnie. Jest to proces złożony i długotrwały. 


\section{Literatura}

Allen D.W. [2011], The Institutional Revolution: Measurement and the Economic Emergence of the Modern World, University of Chicago Press, Chicago.

Allen D.W. [1999], Transaction Costs, http://www2.bren.ucsb.edu/ glibecap/Allentranscosts.pdf (dostęp: 20.12.2015).

Buchanan J.M., Tullock G. [1997], The Calculus of Consent. Logical Foundations of Constitutional Democracy, The University of Michigan Press, Ann Arbor.

Coase R. [1937], The Nature of the Firm, „Economica”, vol. 4, https://doi.org/ $10.2307 / 2626876$.

Coase R. [1990], The Firm, the Market and the Law, The University Chicago Press, Chicago-London.

Coase R. [1992], The Institutional Structure of Production, „The American Economic Review", vol. 82(4).

Furubotn E.G., Richter R. [2000], Institutions and Economic Theory. The Contribution of the New Institutional Economics, The University of Michigan Press, Michigan.

Godłów-Legiędź J. [2005], Instytucjonalna analiza transformacji ustrojowej. Od planu do rynku [w:] Nowa ekonomia instytucjonalna, red. S. Rudolf, WSEiA, Kielce.

Lissowska M. [2008], Instytucje gospodarki rynkowej w Polsce, C.H. Beck, Warszawa.

Małysz J. [2003], Instytucje a koszty transakcyjne w świetle neoinstytucjonalnej ekonomii, „Ekonomista”, nr 3.

North D.C. [1984], Transformation Costs, Institutions and Economics History, „Journal of Institutional and Theoretical Economics", vol. 140.

North D.C. [1990], Institutions, Instituional Change and Economic Performance, Cambridge University Press, Cambridge.

North D.C. [1997], The Contribution of the New Institutional Economics to an Understanding of the Transition Problem, Wider Annual Lectures 1, UNU World Institute for Development Economics Research, Helsinki.

Polanyi K. [1944], The Great Transformation, Beacon Press, Beacon Hill.

Williamson O.E. [1975], Markets and Hierarchies: Analysis and Antitrust Implications, The Free Press, New York.

Williamson O.E. [1998a], Ekonomiczne instytucje kapitalizmu, Wydawnictwo Naukowe PWN, Warszawa.

Williamson O.E. [1998b], Transaction Cost Economics: How It Works; Where It Is Headed, „De Economist”, vol. 146(1151), https://doi.org/10.1023/A:1003263908567.

Williamson O.E. [2000], The New Institutional Economics: Tacking Stock, Looking Ahead, ,Journal of Economic Literature”, vol. 38(3), September, https://doi.org/ 10.1257/jel.38.3.595.

\section{The Concept of Institutional Conditions in the New Institutional Economics} (Abstract)

The role of institutions in the development and functioning of the entire economy is one of the most interesting areas of research of the new institutional economics. In this mainstream, the criterion of minimising transaction costs has been used both for the 
analysis of economic life, as well as all other social institutions. The article examines transaction costs, the institutions underlying the new institutional economics and the importance of institutional conditions in the form of a complete and effective institutional system. In this context, it outlines the problem of the formation and changes in the institutional framework and points to the complexity and specificity of this process.

Keywords: transactional costs, institutions, new institutional economics, path dependence. 